\title{
Redaktörerna har ordet
}

DET HÄR NUMRET ägnar vi i huvudsak åt sociologisk forskning om covid-19-pandemins samhälleliga konsekvenser. Redan kort efter pandemins utbrott, i april 2020, publicerade tidskriften ett samtal mellan fyra svenska sociologer om covid-19-pandemin och vårt samhälles hantering av den. Vi bjöd kort därefter in Shai Mulinari, Linda Soneryd och Susanna Öhman att vara gästredaktörer till ett kommande temanummer med färsk empirisk forskning om hur samhället och människors liv har påverkats av coronakrisen och covid-19-pandemin. Resultatet blev detta dubbelnummer, som på olika sätt ger viktiga inblickar i hur pandemin har påverkat samhället i stort och olika utsatta gruppers livsvillkor. I de olika artiklarna får vi bland annat veta mer om vad svenskarna varit mest oroliga för under pandemin, hur arbetssituationen för personal inom vård och omsorg påverkades av den nya virussjukdomen, hur människor har förhållit sig till "den svenska strategin" i sin vardag och hur dem vars anhöriga har avlidit under pandemin har hanterat de restriktioner som omöjliggjorde ett sista farväl vid dödsbädden. De enskilda artiklarna presenteras mer utförligt i den härpå följande introduktionen av gästredaktörerna, som vi även vill tacka för deras gedigna arbete med numret.

I detta nummer presenterar vi också en ny satsning i form av så kallade research notes eller forskningsnotiser. Den tidigare Lundaredaktionen för tidskriften gav 2017 ut ett helt nummer med sådana forskningsnotiser, under temat "Look at what's happening in Sweden”. Den nuvarande redaktionen vid Södertörns högskola vill nu göra detta till ett stående inslag i Sociologisk Forskning. Forskningsnotiserna är tänkta att presentera nya forskningsresultat i kortare textformat än sedvanliga artiklar. Notiserna ska utgå från egen empirisk forskning om samhällsförhållanden i Sverige, men även komparativa studier som berör svenska förhållanden kan publiceras. Ni hittar en introducerande text som beskriver hur forskningsnotiserna ska utformas längre fram i detta nummer.

I numret finns även recensioner av fem nyutkomma böcker. Två recensioner anknyter till numrets övergripande tema om covid-19-pandemin. I sin recension av Peter Baldwins Fighting the first wave. Why the Coronavirus was tackled so differently across the globe (2021) noterar Anne Kaun att Sverige ges en central roll i boken, och att Baldwin skriver fram sin egen position genom att argumentera för att Sverige tog fel väg i pandemin. Tobias Olofsson recenserar Johan Hirschfeldts och Olof Peterssons Rättsregler i kris (2020), en bok som också diskuterar Sveriges krishantering under coronaviruspandemin. Olofsson menar att författarna gör en ambitiös genomlysning av svensk krislagstiftning och att deras text inte bara är "hantverksmässigt intressant 
utan den är också sociologiskt spännande då de antaganden framställningen bygger på och de slutsatser som presenteras resonerar med centrala sociologiska teman”.

Övriga recensioner i numret behandlar böcker med helt andra teman. Hannah Bradby framhåller att Marie Sépulchres Disability and citizenship studies (2021) är tydlig och välstrukturerad i sitt sätt att undersöka funktionalitet, aktivism och medborgarskap samt sätter dessa teman i relation till frågor som ojämlikhet och social rättvisa. Stina Fernqvist närmar sig Sara Eldéns Forskningsetik. Vägval i samhällsvetenskapliga studier (2020) utifrån tankar kring de konkreta situationer vi som samhällsvetenskapliga forskare återkommande ställs inför: "situationer som kräver självreflektion och som pockar på vår uppmärksamhet med frågor om vad forskningsetik egentligen är i praktiken”. Fernqvist uppmärksammar Eldéns påpekande att en bra forskare kanske alltid måste utstå "en aning ångest" eftersom den samhällsvetenskapliga forskning som inbegriper människor alltid är en komplicerade process. Slutligen tar sig David Scott an Ian Buchanans Assemblage theory and method (2020) genom att diskutera begreppet assemblage - som översatts till "sammansättning" - ett begrepp som fått genomslag inom samhällsvetenskaperna under det senaste decenniet. Scott menar att Buchanans bok saknar resonemang om hur "teoretiska begrepp omsätts i metodologisk praktik", vilket han finner märkligt då boken "har ordet method i titeln".

Vi vill även uppmana er att sända oss era artikelmanus, forskningsnotiser, förslag på recensioner och idéer för framtida temanummer. Sociologisk Forskning publicerar bidrag på svenska och övriga skandinaviska språk samt på engelska. Sociologisk Forskning tillämpar anonymiserad kollegial granskning (double blind peer review) och alla artiklar publiceras med omedelbar öppen tillgång (open access) på tidskriftens hemsida.

\section{Lena Sohl och Magnus Wennerhag}

Redaktörer för Sociologisk Forskning 